\title{
An empirical investigation of picking order theory on hybrid securities: Evidence from Islamic capital market of Malaysia
}

\author{
Mohamad Nizam Jaafar*, Amirul Afif Muhamat, Hairulnizam Hashim, Ismail Ahmad, Sharifah Faigah Syed Alwi
}

Faculty of Business and Management, Universiti Teknologi MARA, 42300 Bandar Puncak Alam, Selangor, Malaysia

\section{A RT ICLE INFO}

\section{Article history:}

Received 7 November 2016

Received in revised form

12 January 2017

Accepted 14 January 2017

\section{Keywords:}

Capital structure

Pecking order theory

Panel data

\begin{abstract}
A B S T R A C T
Capital structure decision is vital in corporate financial management due to its influence on both, return and risk to shareholders. Pecking Order Theory propagates that external capital such as debt or equity is more expensive than internal fund. This is due to the information asymmetric between a firm and investors on the real value of both current operation and future prospect. As such, the objectives of this study are to verify the existence Pecking Order Theory and to examine the determinants of hybrid securities issuance among the Shariah compliant firms in Malaysian Islamic capital market. Notwithstanding Malaysia's position as one of the major players of Islamic Financial Market sector, there are still lack of studies have been carried out to investigate the impact of capital structure theory specifically on the hybrid securities. Therefore, this study is to enrich literature review of capital structure by providing comprehensive analysis of the determinants of hybrid capital structure on Shariah compliant firms in Malaysia especially based on Pecking Order Theory. We use panel data of 50 companies that have been issued the hybrid securities from the year of 2004- 2012. The model shows a positive correlation between leverage CB and the following variables i.e. age, size, tax shield, profitability, financial risk, growth, tangibility, bond market, and GDP growth. Nevertheless, it has a negative relationship with non-tax shield and stock market. As such, Pecking Order theory is applicable to understand the Malaysian Islamic Capital market.
\end{abstract}

(C) 2017 The Authors. Published by IASE. This is an open access article under the CC BY-NC-ND license (http://creativecommons.org/licenses/by-nc-nd/4.0/).

\section{Introduction}

The decision on capital structure is vital in corporate financial management due to its influence on both, return and risk to shareholders. In line with the view of the firm's risk and return, remarkable issue arises on what induce a company to issue a certain type of securities. There are numerous theories that discuss the behavioral aspect of the firms; and Pecking Order Theory which is popularized by Myers and Majluf (1984) is one of the most frequently referred studies for capital structure. This theory was initiated by Donaldson (1961) before Myers and Majluf (1984) came out with a more details on the rationale of the issue. The Pecking Order model is founded on the observation that information asymmetries between new investors and managers who maximize the wealth of

\footnotetext{
* Corresponding Author.

Email Address: mnizam7520@salam.uitm.edu.my (M. N. Jaafar)

https://doi.org/10.21833/ijaas.2017.03.014

2313-626X/@ 2017 The Authors. Published by IASE.

This is an open access article under the CC BY-NC-ND license

(http://creativecommons.org/licenses/by-nc-nd/4.0/)
}

existing stockholders make equity issues more expensive than debt issues, and therefore imply a financing hierarchy. As a result, firms prefer to choose debt rather than equity and experience a negative stock price reaction if the firms are forced to issue equity. The firms will only issue equity when the management of the firms realized that their equity is overpriced. As such, under certain circumstances the managers need to forgo a positive NPV projects if their equity is sufficiently underpriced. The underinvestment problem is avoided by issuing securities with less risk that have less sensitivity to mispricing. Thus, there is a hierarchy of preferences. Firstly, internal funding is preferred followed by riskless debt, risky debt and finally equity

Above and beyond issuance of capital via debt or equity, the firms could also raise capital by more complex securities namely hybrid securities. Hybrid instrument is an innovative instrument of securities which has both the mixture features of equity and debt. Hybrid securities are very essential in the capital market as it could offer a solution for the variance of interest between managers and shareholders. There is always of contradict of 
interest between managers and shareholders. The limited liability of equity holder offers them greater value for investing in more risky projects. This is because when the investment works in favor of the firm, the shareholders have unbounded upside potential. However, if the investment fails, the debt holders will have to bear all the losses. The bondholders responds towards the unfavorable risk that being expose to them by charging higher yield to the issuer/shareholder to compensate their risk which known as the cost of risk shifting. As a solution for the issue, hybrid securities such as convertible bond, allowed the manager to venture into high risk business with lower cost as the convertible bond has lower interest rate than the normal debt instrument. In addition, the feature of conversion option in the convertible bond, permits the bondholders to gain maximize upside prospect of the business venture. The convertible feature also reduces the value of the shareholders' residual claim, which discourages the shareholders to endeavor in more risky projects. This argument is in line with Risk Shifting Theory (Green, 1984). Besides, the literature also offers several other hypothesis that motivated the issuance of hybrid issuance namely Backdoor Equity Financing (Stein, 1992) and Sequential Financing Problem (Myers, 1998).

Despite Islamic finance does not have any element of interest in its activities, the Shariah compliant firms still require financing in the form of debt, equity and hybrid securities respectively. Todate, most of the studies are only focus their studies on developed countries' capital market such as the USA (Titman and Wessels, 1988; Shyam-Sunder and Myers, 1999; Fama and French, 2005) and the UK (Marsh, 1982; Bevan and Dandolt, 2002) and very limited study conducted based on the newly emerged capital market namely Islamic capital market. A remarkable enquiry that arises on this study is what motivates the Shariah compliance firm to issue hybrid security. Does Shariah compliance firms have the similar motivation as what being inspired by conventional firms specifically based Pecking Order Theory.

The paper is organized as follows. Section 2 briefly summarizes the theory of capital structure particularly on the hybrid capital structure. Section 3 discusses the data and empirical method used in this study, Section 4 presents the empirical results of the analysis and Section 5 concludes the paper.

\section{Literature review}

The foundation of the modern theory of capital structure was initiated from Modigliani-Miller (M\&M) theorem, which established by Modigliani and Miller (1958). This theory stated that a firm's capital structure choice does not affect the firm's value when the capital market is prefect or efficient with the assumption of there is no taxes imposed, no issuing cost for raising capital via debt or equity and no agency cost respectively. Nevertheless, it is contradicts to the real world practice which eventually attributes to several other theories were also found to challenge this studies and define the optimal capital structure for the firms in a various perspective such as agency theory (Jensen and Meckling, 1976; Smith and Warner, 1979; Pinegar and Wilbricht, 1989; Lubatkin and Chatterjee, 1994), asymmetric information (Ackerloff, 1970; Myers and Majluf, 1984; Hasbrouck, 2005), pecking order theory (Myers and Majluf, 1984; Myers, 2001; Fama and French, 1998; 2005), bankruptcy cost (Berger and Ofek, 1995; Florackis, 2008), risk shifting (Green, 1984; Lewis et al., 1999) and backdoor equity financing (Stein, 1992; Lewis et al., 1999).

The theory of capital structure has been dominated by the search for optimum capital structure such as Trade Off Theory (Modigliani and Miller, 1958) which the tradeoff between the benefit of taxes advantages of borrowed money and the cost of financial distress when the firm is highly leverage. On the other hand, the Pecking Order Theory does not take an optimal capital structure as a starting point but propose firm prefer to use internal finance over external fund. If the internal fund is insufficient to support the expansion activities, firm will choose among various external financing in such a way as to curtail any additional cost of asymmetric information. The attribute Pecking Order of financing is as preference for financing as follows: internal fund namely retained earning followed by debt and the last resort will be equity.

For hybrid selection, Green (1984) proposed the employment of hybrid financing as an alternative for debt sequentially to minimize agency cost from the conflict of interest between bondholder and stockholder. According to Jensen and Meckling (1976), the limited liability of equity holder, offers them greater value for investing in more risky projects. This is due to as the investment work in good turn of the firm, the shareholder have limitless advantage potential. Nonetheless, if the investment be unsuccessful, the debt holder will have to go through all the losses. This situation is called risk shifting problem. As such, the bondholder is responding the unfavorable risk that being expose to them by charging higher yield to the issuer/shareholder to compensate their risk which known as the cost of risk shifting. The feature of conversion option in the hybrid security such as convertible bond, permit the bond holder to gain maximize upside prospect of the business venture. Besides that, the convertible also reduce the value of the shareholders' residual claim which discourages the shareholder to endeavor in more risk projects. Thus, Green (1984) predicted that convertible bonds are a substitute for straight debt and the substitution of convertibles is most likely to occur in firms facing significant risk incentive problems.

Besides addressing on the conflict of interest between the managers, Stein (1992) proposed that backdoor equity financing theory that the firms are able to delay issuance of equity via hybrid financing when they face high degree of informational asymmetries cost making less attractive to issue 
equity. As such, convertible debt stand for a financing option that diminished the unpleasant selection costs of an immediate sale of equity. This facilitates the firms to issue equity without having to acquire higher financial risk. Thus, Lewis et al. (1999) argued that although convertible debt issuers may have firm characteristics that are similar to equity issuers, leveraged firms that are optimistic about their future investment opportunities but that are subject to significant information asymmetries, are more likely to choose convertible debt or straight debt. However, Stein (1992) noted should the firm that having significant asymmetric information proceed with the issuance of straight debt may attribute to firms to face other value decrease costs. When the financial distress is very expensive, firms that are highly gearing and have poor future cash flow will relinquish straight debt issues. Consequently, financial distress costs prevail over unfavorable selection costs. Stein (1992) concluded that convertible bonds are a replacement for equity and that this substitute is most probable to take place in firms facing major information asymmetries and high financial distress costs.

In addition, the popular dispute among practitioners on why they are choosing for issuing the hybrid securities instead of debt i.e. convertible bond is because of the cost factor. Convertible bond carry lower coupon rate as compared to the normal bond and subsequently permit the issuers to sell the security at a premium over the current prices where the conversion price is higher that the stock price (Myers, 2000). This is in line with Mayer's model of Sequential Financial problem (Myers, 1998), which is extension from the "backdoor equity hypothesis model" (Stein, 1992).

\section{Empirical methodology and measurement of the variables}

The sample consists of 50 listed firms that are Shariah compliance listed on Bursa Malaysia and Ace Market over the years 2004-2012. The companies selected are consisting of the one that have issued hybrid securities namely convertibles bond and loan stock during the period under review.

Generally, there are various types of hybrid instruments in Malaysia capital market namely bond with convertible loan, bond with warrant, structured warrant, company warrant, loan stock and others. Nevertheless, due to limited issuance by the firms, we only include convertible bond and loan stock for our model of study. Besides, we are also assuming that all hybrid issuance securities by Shariah compliant firms as the Islamic hybrid securities. This is because not all Shariah compliant firms are issuing Islamic hybrid securities per se and there are also under some circumstances that non Shariah firms are issuing Islamic hybrid products. Hopefully, in the future, all these Shariah compliant firms will only issue Islamic hybrid securities for capital requirement.

\subsection{Empirical model}

To test the Pecking Order Theory in the hybrid capital structure in the Malaysia Islamic capital market, the hybrid leverage ratios of individual firms are modeled as a function of several firm specific factors in a cross sectional framework. As such, this study will incorporate all the attributes that were described in the next section. The general estimation model is as follows:

$$
\begin{aligned}
\text { LEV } i t=\alpha+\beta i 1 \text { SIZEit }+\beta i 2 A G i t+\beta i 3 T S i t \\
+\beta i 4 N T S i t+\beta i 5 \text { PROFit }+\beta i 6 T \text { Ait } \\
+\beta i 7 \text { Grit }+\beta i 8 F R+\beta i 9 F F U i t
\end{aligned}
$$

where, LEV it is measured by total hybrid capital namely convertible bond and loan stock divided by the firm's shareholders fund.

The analysis will be based on panel data that is conducted via observations on the same crosssectional or individual, units over several time periods. It performed together with the time series of cross sectional observations and therefore provides larger data points, more variability and therefore increases the degree of freedom and minimizes the collinear among variables.

Panel data also consist of dynamics of change in data. As such, we estimated our model of the study via dynamic estimator namely General Method of Moment (GMM). Besides, based on our testing in Table 1 and 2, the data is not normally distributed. As such, the study require dynamic estimator i.e. GMM. The following is the explanation on the theoretical relationship between independent variable and the variables that suggested in the literature as determinants of hybrid securities issuance. GMM is explained based on Eq. 1.

Referring to the basic assumption, error term $\overline{\mathrm{u}}$ $=0$. Therefore, from the regression $y=b_{x}+u$, we can get the coefficient, $b=\left(X^{\prime} X^{\prime}\right)^{-1} X^{\prime} y^{51,} n$ the form of matrices and $\hat{y}=X\left(X^{\prime} X\right)^{-1} X^{\prime} y=$ Pxy because $y=b x+u$, where $P_{x}$ is a projection matrix. Based on the assumptions of the instruments, $\operatorname{cov}(\mathrm{z}, \mathrm{x}) \neq 0$ and $\operatorname{cov}(\mathrm{z}, \varepsilon)=0$, the IV estimator can be written as the following (Eq. 1).

$E\left\{u_{i}, z i\right\}=E\left\{\left(y_{i}-x_{i}^{\prime} b\right) z_{i}\right\}=0$

where, $\mathrm{z}$ is $\mathrm{T} x \mathrm{k}$ instruments which satisfy the moment condition, $\mathrm{E}\left(\mathrm{Z}^{\prime}{ }_{\mathrm{i}} \mathrm{u}_{\mathrm{i}}\right)=0$; and $\mathrm{b}_{\mathrm{iv}}=\left(\mathrm{Z}^{\prime} \mathrm{X}\right)^{-1} \mathrm{Z}^{\prime} \mathrm{y}$ if endogenous variables are just identified.

When it is over identification, then the instrument matrix is not symmetric and is not possible to calculate. To resolve this, we require minimizing quadric form with weighting matrix $\mathrm{W}_{\mathrm{N}}$ (Eq. 2).

$Q N(b)=\left[N-1 Z^{\prime}(y-X b)\right]^{\prime} W N\left[N-1 Z^{\prime}(y-X b)\right]$

This entailed $X^{\prime} Z W_{N} Z^{\prime} y=X^{\prime} Z W_{N} Z^{\prime} X b_{i v}$ and $b_{i v}=$ $\left(X^{\prime} Z W_{N} Z^{\prime} X\right)^{-1} X^{\prime} Z W_{N} Z^{\prime} y$ as $W_{N}$ pursue the method of moment with minimizing the quadric loss function, the optimal weighting matrix is (Eq. 3): 
$N^{-1} \sum_{i=1}^{N} Z_{i} Z_{i}^{\prime}$

The IV is a special case of GMM. When an equation is just identified, IV and GMM turn up at the same result. Unlike the IV estimator, GMM does not require i.i.d of error term. Just like IV, coefficients of GMM are decided by (Eq. 4):

$B_{G M M}=\left(\mathrm{X}^{\prime} \mathrm{ZW}_{\mathrm{NZ}} \mathrm{Z}^{\prime} \mathrm{X}\right)^{-1} \mathrm{X}^{\prime} \mathrm{ZW}_{N} \mathrm{Z}^{\prime} \mathrm{y}$

The estimator of GMM on $\mathrm{W}_{\mathrm{N}}, \mathrm{W}_{\mathrm{N}}=\left(\mathrm{N}^{-1} \sum \hat{\mathrm{U}}^{2} \mathrm{ZiZ}_{\mathrm{i}}^{\prime}\right)^{-1}=$ (Z'uu'Z) $^{-1} 53$ where weighing matrix $W_{N}$ is a covariance matrix. Thus, the GMM allows heteroskedasticity of $\mathrm{u}_{\mathrm{i}}$ (Davidson and Mackinnon, 2004; Baum, 2006; Verbeek, 2008). Therefore, the GMM estimator becomes (Eq. 5):

$b_{G M M}=\left(X^{\prime} Z\left(Z^{\prime} u u^{\prime} Z\right)^{-1} X^{\prime} Z\left(Z^{\prime} u u Z\right)^{-1} Z^{\prime} y\right.$

Therefore, the study includes a lagged dependent variable and new error term on the right hand of the Eq. 1 (Eq. 6).

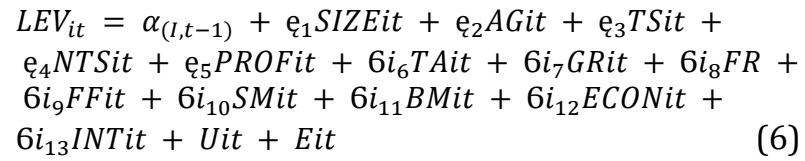

\subsection{Empirical relationship between leverage and its independent variables}

\subsubsection{Company size (SIZE)}

Natural logarithm of total assets (Warner, 1977; Titman and Wessel, 1988; Rajan and Zingales, 1995; Gaud et al., 2005): The issuing of capital is based on the size of the company. The established firm is more preferable to issue debt in line with trade off theory (Titman and Wessel, 1988). It recommended that the larger company has the lesser possibility of default, which feature to better entrance to credit market.

\subsubsection{Age (AG)}

Various capital structure studies considered age of the firm as one of the important determinant of capital structure (Bhaduri, 2002; De Andres et al., 2005; Crabbe and Post, 1994). The asymmetric information theory by Harris and Raviv (1991) and Myers and Majluf (1984) that established firms are well known institutions.

\subsubsection{Tax consideration}

\subsubsection{Debt tax shield (TS)}

The ratio of tax paid over total asset (Suchard and Singh, 2006). According to trade off theory (Modigliani and Miller, 1963), the firms that record high tax shield are more likely to take advantage of interest deduction from tax by issuing debt. By opting to debt financing, the features of interest that allow tax deductibility would raise the firm's after tax cash flow.

\subsubsection{Non-debt tax shield (NTS)}

The ratio of depreciation to total asset (Titman and Wessels, 1988; Ozkan, 2001): As suggested by the tradeoff theory (Modigliani and Miller, 1963), firms can use non debt tax shield such as depreciation to save corporate tax. Therefore, a higher non debt tax shield such as depreciation and investment tax credit deduction, lower the possibility tax benefit of debt and the firms opt issuance of other than debt i.e. equity, convertible debt.

\subsubsection{Profitability (PROF)}

Earnings before interest and Tax divided by total assets (Rajan and Zingales, 1995; Gaud et al., 2005). The calculation of earnings before interest and Tax divided by total assets for ratio of profitability is widely used by many studies. The firms optimal financing and success in assets utilizations are reflected in the firms' profitability as stated by Myers (1977) in pecking order theory (Myers and Majluf, 1984; Booth et al., 2001).

\subsubsection{Asset tangibility (TA)}

The ratio of total fixed asset to total asset (Guad et al., 2005). This proxy is related to the tradeoff theory (Modigliani and Miller, 1963). The firms that recorded higher asset tangibility reflecting that the firms are having more collateral. As such, they have more tendencies to raise capital via issuing debt with lower cost of interest in conjunction with firm's low risk of bankruptcy.

\subsubsection{Growth opportunity (GR)}

Annual growth rate in sales (Titman and Wessel, 1988): There is various measures have been adopted by various studies. Rajan and Zingales (1995) used market to book ratio as the proxy for growth. Nevertheless, according to Titman and Wessel (1988), the growth of revenue reflects better proxy for the growth opportunity.

\subsubsection{Financial flexibility (FF)}

Cash and Marketable Securities over current assets (Singh and Hodder, 2000): This variable is only being recently applied in the study of the determinant of corporate capital structure. In general, the current literature has given only one description on financial flexibility namely the ratio of cash and marketable securities over current assets (Singh and Hodder, 2000; Upneja and Dalbor, 1999). 


\subsubsection{Financial risk (FR)}

Long term debt to total asset (Suchard and Singh, 2006): According to Suchard and Singh (2006), the firms that have high financial risk will be more likely to issue equity or from the prospective of hybrid instrument will be warrant. This is in line with pecking order model, financial distress cost and sequential financing model hypothesis respectively. This is in conjunction with the result found in Jung et al. (1996) that examine the selection between straight debt and equity.

\subsection{Descriptive analysis}

In addition to the mean-median comparison and standard deviation, the data is also tested using numerous methods such as the skewness test, kurtosis, the Jarque Bera respectively. This is to discover the data under review are normally distributed or otherwise.

Table 1 reflects that the data under review are not normally distributed. Exception to LEV, SIZE, TANG and FR the values of mean and median as shown in column one and two are not the equal. Only SIZE, Tangibility, FR, Stock Market, Bond Market and Interest rate have the skewness of the variables, equal to approximately zero. Finally, the values of Jarque-Bera as indicated in the Table 1, apart from being significant, it rejects the hypothesis that the data are normally distributed. These preliminary findings reveal that the estimation model using OLS could not generate better model. Instead, GMM is more suitable and expected to produce better estimation model as GMM manage to address the issue of heteroscedasticity and endogeneity in the data under review.

Table 1: Descriptive statistic

\begin{tabular}{|c|c|c|c|c|c|c|}
\hline Variables & Mean & Median & Std Dev & Skewness & Kurtosis & Jerque Bera \\
\hline Lev & 0.0921 & 0.068 & 0.099 & 4.987 & 41.24 & $\begin{array}{c}19070.19 \\
0.0000\end{array}$ \\
\hline AGE & 27.95 & 25.00 & 17.45 & 0.9688 & 4.22 & $\begin{array}{c}64.21 \\
0.0000\end{array}$ \\
\hline SIZE & 6.07 & 6.01 & 0.069 & 0.6229 & 3.82 & $\begin{array}{c}27.28 \\
0.0000\end{array}$ \\
\hline TS & 0.0082 & 0.0079 & 0.008 & -0.1213 & 15.28 & $\begin{array}{c}27.28 \\
0.0000\end{array}$ \\
\hline NTS & 0.0169 & 0.0133 & 0.013 & 3.8768 & 22.69 & $\begin{array}{l}5468,7 \\
0.0000\end{array}$ \\
\hline PROF & 0.0739 & 0.07 & 0.068 & -1.478 & 24.62 & $\begin{array}{c}5815 \\
0.0000\end{array}$ \\
\hline TA & 0.448 & 0.419 & 0.13 & 1.5 & 6.735 & $\begin{array}{l}279.87 \\
0.0000\end{array}$ \\
\hline GR & 0.1806 & 0.17 & 1.635 & 14.33 & 142.69 & $\begin{array}{c}215803 \\
0.0000\end{array}$ \\
\hline FR & 0.3838 & 0.375 & 0.175 & -0.11 & 2.47 & $\begin{array}{c}4.17 \\
0.0000\end{array}$ \\
\hline $\mathrm{FF}$ & 0.1248 & 0.114 & 0.1101 & 1.67 & 14.039 & $\begin{array}{c}1637.56 \\
0.0000\end{array}$ \\
\hline SM & 138.9868 & 144.66 & 26.4733 & -0.925 & 3.15 & $\begin{array}{c}39.43 \\
0.0000\end{array}$ \\
\hline BM & 84.207 & 85 & 8.417 & 0.022 & 1.39 & $\begin{array}{c}27.89 \\
0.0000\end{array}$ \\
\hline GDP & 4.871 & 5.58 & 2.659 & -1.725 & 4.607 & $\begin{array}{l}156.43 \\
0.0000\end{array}$ \\
\hline BFR & 6.283 & 6.27 & 0.3739 & -0.644 & 2.536 & $\begin{array}{c}20.21 \\
0.0000\end{array}$ \\
\hline
\end{tabular}

\section{Results and discussion}

The model shows a positive correlation between leverage $\mathrm{CB}$ and the following variables i.e. age, size, tax shield, profitability, FR, growth, tangibility, BM and GDP growth. Nevertheless, it has a negative relationship with non-tax shield and SM. The positive significant relationship between debt hybrid and TS and the negative relationship between debt hybrid and non-tax shield respectively is in line with Pecking Order theory. The firm implement financing choice based on hierarchy from the cheapest cost namely retain earning to the most expensive i.e. equity. Since debt is cheaper than equity, the profitable firm will always opt for debt before choosing equity. This indicates that Pecking Order
Theory is valid in Malaysian Islamic capital market condition.

Meanwhile, the risk and profitability are considered the most determinant factors for issuing convertible bond and loan stock. These results suggest that, the firms that expose with high risk but strong financial position will choose convertible bond. This can be related to the scenario in Malaysia where the authorities emphasize on conservative credit policies. Malaysian financial institutions generally offer debt to strong financial position firms that hold low risk of financial distress or bankruptcy. Since the high risk firms but profitable are difficult to secure additional credit facility from the financial institutions, there always opt for hybrid security of convertible bond as proposed by risk shifting theory where hybrid securities allow the high risk firm to further venture into riskier business (Table 2). 


\section{Conclusion}

This research concluded that the determinants which are significant in hybrid securities issuance for debt were signified by the convertible bond and loan stocks.

The estimation result for hybrid securities of convertible bond and loan stock demonstrates that coefficient for Age, Size, Tax Shield, Profitability, Financial Risk, Financial Flexibility, Tangibility, GDP, interest and Bond Market are having significant positive relation with the model under review. Meanwhile, NTS and SM show a negative correlation.
TS is show a positive correlated indicate that the profitable firm will opt for the cheapest sources of funding namely debt instead of equity. As such, Pecking Order theory is applicable to Malaysian Islamic Capital market. In addition, from the model also reveal that risk and growth are considered as the most determinant factors for issuing convertible bond and loan stock. By issuing hybrid securities of convertible bond, the firms are able to achieve tax saving and minimize the of conflict of interest between debt manager who decline to venture high risk and equity stakeholder that favor to venture into high risk business respectively.

Table 2: System GMM on model 1

\begin{tabular}{ccccccc}
\hline Leverage & Coef. & Std Error & $\mathrm{Z}$ & $\mathrm{P}>[\mathrm{z}]$ & \multicolumn{2}{c}{$[$ 95\% Conf. Interval] } \\
\hline L1 & 0.0492 & 0.0263 & 1.87 & 0.042 & -0.01770 & 0.729 \\
Age & 0.0612 & 0.0319 & 1.92 & 0.047 & 0.0152 & 1.531 \\
Size & 0.8321 & 0.3438 & 2.42 & 0.014 & 0.0551 & 4.781 \\
Tax shield & 0.6903 & 0.1717 & 4.02 & 0.000 & 0.3115 & 2.102 \\
Non tax shield & -0.1143 & 0.0386 & -2.96 & 0.003 & -2.1541 & 3.445 \\
Profitability & 0.9112 & 0.4821 & 1.89 & 0.041 & -0.2313 & 4.123 \\
Tangibility & 0.7174 & 0.2104 & 3.41 & 0.000 & 0.0512 & 1.714 \\
Growth & 0.0731 & 0.0234 & 3.13 & 0.001 & -2.0134 & 2.123 \\
Financial Risk & 0.0313 & 0.0080 & 3.92 & 0.000 & -2.0121 & 2.124 \\
Financial Flexibility & 0.2231 & 0.0538 & 4.15 & 0.000 & 0.2094 & 0.7367 \\
SM & -0.0034 & 0.0016 & -2.13 & 0.033 & 0.00023 & 0.00056 \\
BM & 0.0056 & 0.0030 & 1.89 & 0.049 & 0.00011 & 0.00061 \\
GDP growth & 0.0321 & 0.0226 & 1.42 & 0.042 & 0.00413 & 0.54321 \\
cons & 2.323 & 0.7328 & 3.17 & 0.031 & 0.0213 & 6.123
\end{tabular}

No of instruments: 40; No of observations: $173 ;$ Wald chi $^{2}$ (12): 18.33; Prob > chi2: 0.1061; Arrelano Bond test for AR(1) in first differences: $z=-1.72$

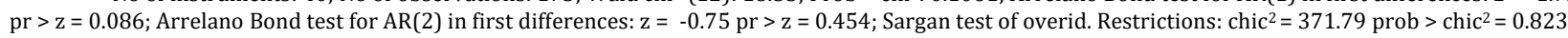
Sargan test, chic $^{2}$ is insignificant-the model is not exogenous

\section{References}

Ackerloff G (1970). The market for lemons: Quality uncertainty and the market mechanism. Quarterly Journal of Economics, 84(3): 488-500.

Baum CF (2006). An introduction to modern econometrics using Stata. Stata Press, Texas, USA

Berger PG and Ofek E (1995). Diversification's effect on firm value. Journal of Financial Economics, 37(1): 39-65.

Bevan AA and Dandolt J (2002). Capital structure an dits determinants in the UK-A descompositional analysis. Applied of Financial Economics, 12(3): 159-170.

Bhaduri S (2002). Determinants of corporate borrowing: Some evidence from the Indian corporate structure. Journal of Economics and Finance, 26(2): 200-215.

Booth L, Aivazian V, Demirguc-Kunt A, and Maksimovic V (2001). Capital structures in developing countries. Journal of Finance, 56(1): 87-130

Crabbe L and Post MA (1994). The effect of a rating downgrade on outstanding commercial paper. Journal of Finance, 49(1): 39. 56.

Davidson R and MacKinnon JG (2004). Econometric theory and methods. Oxford University Press, New York, USA.

De Andres P, Azofra V, and Lopez F (2005). Corporate boards in OECD countries: Size, composition, functioning and effectiveness. Corporate Governance: An International Review, 13(2): 197-210.

Donaldson G (1961). Corporate debt capacity. Harvard University, Massachusetts, USA.

Fama EF and French KR (2005). Financing decisions: Who issues stock? Journal of Financial Economics, 76(3): 549-582.

Fama F and French R (1998). Taxes, financing decisions, and firm value. Journal of Finance, 53(3): 819-843.
Florackis C (2008). Agency costs and corporate governance mechanisms: Evidence for UK firms. International Journal of Managerial Finance, 4(1): 37-59.

Gaud P, Jani E, Hoesli M, and Bender A (2005). The capital structure of Swiss companies: an empirical analysis using dynamic panel data. European Financial Management, 11(1): 51-69.

Green R (1984). Investment incentives, debt and warrants. Journal of Financial Economics, 13: 115-136

Harris M and Raviv A (1991). The theory of capital structure. The Journal of Finance, 46(1): 297-355.

Hasbrouck J (2005). Trading costs and returns for US equities: The evidence from daily data. Working Paper, Department of Finance, Leonard N. Stern School of Business, New York University, Brooklyn, USA.

Jensen MC and Meckling WH (1976). Theory of the firm: Managerial behavior, agency costs and ownership structure. Journal of Financial Economics, 3(4): 305-360.

Jung K, Kim YC, and Stulz R (1996). Timing, investment opportunities, managerial discretion, and the security issue decision. Journal of Financial Economics, 42(2): 159-186.

Lewis CM, Rogalski RJ, and Seward JK (1999). Is convertible debt a substitute for straight debt or for common equity?. Financial Management, 28(3): 5-27.

Lubatkin M and Chatterjee S (1994). Extending modern portfolio theory into the domain of corporate diversification: Does it apply?. Academy of Management Journal, 37(1): 109-136.

Marsh P (1982). The choice between equity and debt: An empirical study. Journal of Finance, 37(1): 121-144.

Modigliani F and Miller M (1963). Corporate income taxes and the cost of capital: A correction. American Economic Review, 53(3): 433-443. 
Modigliani F and Miller MH (1958). The cost of capital, corporate finance and the theory of investment. The American Economic Review, 48(3): 261-297.

Myers SC (1977). Determinants of corporate borrowing. Journal of Financial Economics, 5(2): 147-175.

Myers SC (1998). Why firms issue convertible bonds: The matching financial and real investment options. Journal of Financial Economics, 47(1): 83-102.

Myers SC (2000). Convertible bonds: Matching financial and real option. Journal of Applied Corporate Finance, 13(1): 8-21.

Myers SC (2001). Capital structure. Journal of Economic Perspectives, 15(2): 81-102.

Myers SC and Majluf NS (1984). Corporate financing and investment decisions when firms have information that investors do not have. Journal of Financial Economics, 13(2): 187-221.

Ozkan A (2001). Determinants of capital structure and adjustment to long run target: Evidence from UK company panel data. Journal of Business Finance and Accounting, 28(1-2): 175 198.

Pinegar JM and Wilbricht L (1989). What managers think of capital structure theory: A survey. Financial Management, 18(4): 82-91.

Rajan RG and Zingales L (1995). What do we know about capital structure? Some evidence from international data. Journal of Finance, 50(5): 1421-1460.
Shyam-Sunder L and Myers SC (1999). Testing static tradeoff against pecking order models of capital structure. Journal of Financial Economics, 51(2): 219-244.

Singh K and Hodder JE (2000). Multinational capital structure and financial flexibility. Journal of International Money and Finance, 19(6): 853-884.

Smith CW and Warner JB (1979). On financial contracting: An analysis of bond covenants. Journal of Financial Economics, $7(2): 117-162$.

Stein JC (1992). Convertible debt as backdoor equity financing. Journal of Financial Economics, 32(1): 3-21.

Suchard JA and Singh M (2006). The determinants of the hybrid securities issuance decision for Australian firms. Pacific Basin Finance Journal, 14(3): 269-290.

Titman S and Wessels R (1988). The determinants of capital structure choice. Journal of Finance, 43(1): 1-19.

Upneja A and Dalbor MC (1999). An examination of leasing policy, tax rates, and financial stability in the restaurant industry. Journal of Hospitality and Tourism Research, 23(1): 85-99.

Verbeek M (2008). A guide to modern econometrics. John Wiley and Sons, New Jersey, USA.

Warner J (1977). Bankruptcy costs: Some evidence. Journal of Finance, 32(2): 337-347. 